\title{
PENINGKATAN PEMBELAJARAN LARI JARAK PENDEK MELALUI PENDEKATAN BERMAIN LARI BOLA KERANJANG
}

\author{
${ }^{1}$ Wening Nugraheni, ${ }^{2 B A c h t i a r,}{ }^{3}$ Dwi Desti Daryani $\bowtie$ \\ 123Uniersitas Muhammadiyah Sukabumi \\ $\triangle$ ddwidesti@gmail.com
}

\begin{abstract}
ABSTRAK
Tujuan dari penelitian ini adalah untuk mengetahui peningkatan hasil belajar lari jarak pendek melalui pendekatan bermain lari bola keranjang. Penilaian ini melibatkan seluruh siswa kelas III di SD Negeri 05 Karangtengah, yang hadir dalam penelitian yaitu berjumlah 25 orang. Pengumpulan data menggunakan instrumen tes lari jarak pendek. Penelitian ini dilaksanakan selama tujuh minggu dengan satu kali pertemuan untuk melaksanakan tes kondisi awal (pra siklus), enam kali pertemuan dengan dua kali pertemuan untuk pelaksanaan siklus I, dua kali pertemuan untuk pelaksanaan siklus II, dan dua kali pertemuan untuk pelaksanaan siklus III. Dari hasil penelitian diperoleh kesimpulan bahwa melalui pendekatan bermain, pembelajaran lari jarak pendek pada siswa mengalami peningkatan yang signifikan dari tiap siklusnya dibuktikan dengan hasil tes evaluasi pada pra siklus nilai tertinggi 75 , nilai terendah 50, rata- rata 62,6, presentase ketuntasan siswa 24\%. Pada siklus I nilai tertinggi 75, nilai terendah 50, rata- rata 67,2, presentase ketuntasan siswa 52\%. Pada siklus II nilai tertinggi 80, nilai terendah 55, rata- rata 71,6, presentase ketuntasan siswa 68\%. Pada siklus III nilai tertinggi 90, nilai terendah 65 , rata- rata 80,2, presentase ketuntasan siswa 88\%. Hasil analisis angket dapat disimpulkan bahwa dengan melalui pendekatan bermain lari bola keranjang siswa lebih semangat dan tidak merasa jenuh serta aktif dalam proses pembelajaran lari jarak pendek.
\end{abstract}

\section{Kata kunci : Pendekatan Bermain Lari Bola Keranjang}

\section{ABSTRAC}

The purpose of this study was to determine the increase in learning outcomes for short distance running through the playing basketball approach. This assessment involved all third grade students at SD Negeri 05 Karangtengah, who attended the study, amounting to 25 people. Data collection used instruments sprint tests. This research was conducted for seven weeks with one meeting to carry out the initial condition test (pre-cycle), six meetings with two meetings for the implementation of cycle I, two meetings for the implementation of cycle II, and two meetings for the implementation of cycle III. From the research results, it was concluded that through the play approach, learning to run short distances in students experienced a significant increase in each cycle as evidenced by the results of the evaluation test in the pre-cycle the highest score was 75, the lowest score was 50, the average was 62.6, the percentage of student completeness was $24 . \%$. In the first cycle the highest score was 75, the lowest score was 50, the average was 67.2, the percentage of student completeness was 52\%. In the second cycle the highest score was 80, the lowest score was 55, the average was 71.6, the percentage of student completeness was $68 \%$. In the third cycle the highest score was 90, the lowest score was 65, the average was 80.2, the percentage of student completeness was $88 \%$. The results of the questionnaire analysis can be concluded that through the playing basketball approach the students are more enthusiastic and do not feel bored and are active in the learning process of short distance running.

\section{Keywords: Basketball Running Approach}

Alamat Korespondensi: Universitas Muhammadiyah Sukabumi

$\bowtie$ Email: ddwidesti@gmail.com
(C) 2020 STKIP Pasundan ISSN 2721-5660 (Cetak) ISSN 2722-1202 (Online) 


\section{PENDAHULUAN}

Atletik salah satu materi pelajaran yang ada dalam mata pelajaran pendidikan jasmani olahraga dan kesehatan di sekolah baik tingkat SD, SMP, maupun SMA. Gerakan-gerakan dalam atletik seperti jalan, lari, lompat, dan lempar. Istilah "atletik" berasal dari bahasa Yunani yaitu "athlon" yang berarti berlomba atau bertanding. Atletik adalah aktivitas jasmani atau latihan fisik yang berisikan gerakan-gerakan alamiah atau wajar seperti jalan, lari, lompat dan lempar. Atletik memegang peranan penting dalam pengembangan kondisi fisik, dan sering menjadi dasar pokok untuk pengembangan maupun peningkatan prestasi yang optimal bagi cabang olahraga yang lain.

Pada pelaksanaan pembelajaran Penjasorkes khususnya atletik nomor lari jarak pendek, yang dilakukan oleh beberapa sekolah yang ada di Kabupaten Sukabumi pada umumnya dan di SD Negeri 05 Karangtengah pada khususnya, menunjukkan bahwa proses pembelajaran lari jarak pendek yang dilakukan seperti yang diajarkan orang dewasa, cenderung menggunakan pendekatan olahraga prestasi dalam pembelajarannya. Sedangkan anak-anak sekolah dasar lebih suka bermain yang akhirnya anak-anak dalam pembelajaran atletik nomor lari jarak pendek merasa tidak menyenangkan atau membosankan.

Guru masih senantiasa memberi materi pembelajaran atletik nomor lari jarak pendek dengan mengacu pada hasil yang dicapai siswa tidak memperhatikan proses yang dilakukan, yang lebih disayangkan bahwa teknik yang digunakan sangat membosankan sehingga yang seharusnya anak sudah terbiasa dengan gerakan dasar atletik menjadi kurang bersemangat dalam mengikutinya. Padahal untuk meningkatkan kompetensi siswa dalam gerak dasar atletik nomor lari jarak pendek dibutuhkan metode yang sifatnya menarik dan tidak membosankan. Dengan demikian guru dituntut untuk bisa menentukan metode yang tepat, sesuai dengan karakter siswa yang masih suka bermain sehingga bisa direspon baik oleh siswa.

Sedangkan untuk karakteristik anak usia kelas III Sekolah Dasar cenderung senang bermain dan aktif untuk melakukan setiap gerakan yang diperintahkan, yang tentunya tetap harus dalam pengawasan yang ketat. Berdasarkan hal tersebut, maka sebaiknya proses pembelajaran dilakukan dengan rasa senang dan gembira oleh para siswa. Disini kiranya penulis ingin mencoba menerapkan proses pembelajaran lari jarak pendek melalui permainan lari bola keranjang yang diharapkan dengan permainan ini para siswa akan bergerak lebih aktif dan termotivasi dalam belajarnya sehingga meningkatkan hasil belajarnya.

\section{METODE}

Metode yang digunakan dalam penelitian ini adalah metode Penelitian Tindakan Kelas (Classroom Action Research). Metode penelitian tindakan kelas (PTK) merupakan bagian dari penelitian tindakan (action research) yang dilakukan oleh guru dan dosen di kelas (sekolah dasar dan perguruan tinggi) tempat ia mengajar yang bertujuan memperbaiki dan meningkatkan kualitas dan kuantitas proses pembelajaran di kelas.

Menurut Iskandar (2012:20), PTK suatu kegiatan ilmiah yang terdiri dari kata penelitian, tindakan dan kelas.

a. Penelitian merupakan kegiatan mencermati suatu objek menggunakan aturan metodologi untuk memperoleh data atau informasi yang bermanfaat untuk meningkatkan mutu suatu hal yang menarik minat dan penting bagi peneliti.

b. Tindakan merupakan suatu gerak kegiatan yang sengaja dilakukan dengan tujuan tertentu yang dalam penelitian berbentuk rangkaian siklus kegiatan.

c. Kelas merupakan sekelompok peserta didik yang sama dan menerima pelajaran yang sama dari seseorang guru.

Jadi, yang disebut PTK merupakan suatu penelitian mengenai kegiatan yang secara sengaja dilakukan oleh seorang guru di dalam sebuah kelas. PTK merupakan kegiatan yang sangat mudah apabila guru menyadari bahwa sesungguhnya sering terdapat masalah dalam kegiatan belajar mengajar. Masalah- masalah itulah yang seharusnya melandasi seorang guru untuk 
melaksanakan kegiatan PTK untuk meningkatkan kualitas hasil belajar mengajar. Untuk instrumen yang digunakan adalah lembar observasi, angket dan tes lari jarak pendek.

Data hasil pengamatan dianalisis secara deskriptif. Sedangkan data hasil kuesioner dianalisis secara kuantitatif. Pengolahan data dilakukan selama penelitian dari awal sampai akhir. Langkahlangkah pengolahan data yaitu penyelesaian gambaran hasil penelitian. Data- data yang dikumpulkan selanjutnya disajikan berupa tabel, diagram, grafik, dengan tujuan memudahkan dalam membaca data.

Pada kegiatan ini peneliti berusaha menelaah temuan- temuan berdasarkan kerangka teoritik yang di pilih mengacu kepada norma- norma praktis yang disetujui. Analisis dan kualitatif menggunakan presentase sedangkan analisis kuantitatif dengan cara mencari nilai dan variasi.

Tabel 1. Kriteria Penilaian Lari Jarak Pendek

\begin{tabular}{|l|c|l|}
\hline \multicolumn{3}{|c|}{ Kriteria Penilaian } \\
\hline \multicolumn{1}{|c|}{ Putra } & Nilai & \multicolumn{1}{c|}{ Putri } \\
\hline$<6,3$ detik & 90 & $<6,7$ detik \\
\hline $6,4-6,9$ detik & 85 & $6,8-7,2$ detik \\
\hline $7,0-7,7$ detik & 80 & $7,3-8.0$ detik \\
\hline $7,8-8,8$ detik & 75 & $8,1-9,1$ detik \\
\hline $8,9-9,9$ detik & 70 & $9,2-10,2$ detik \\
\hline $10-11$ detik & 65 & $10,3-11,3$ detik \\
\hline $11,1-12,1$ detik & 60 & $11,4-12,4$ detik \\
\hline $12,2-13,2$ detik & 55 & $12,5-13,5$ detik \\
\hline$>13,3$ detik & 50 & $>13,6$ detik \\
\hline
\end{tabular}

Sumber: (http://smacepiring.wordpress.com)

Angket merupakan teknik mengoleksi data yang digunakan oleh peneliti yang dikembangkan berdasarkan teori yang digunakan. Butir pertanyaan dalam angket dikembangkan berdasarkan kisi-kisi yang disusun oleh peneliti, di dalam kisis tersebut tercakup variabel, indikator, sub indikator dan jumlah butir pertanyaan. Angket siswa yang digunakan dalam penelitian ini untuk mengukur sikap dan tanggung jawab siswa terhadap metode pembelajaran yang dikembangkan. Derajat penilaian siswa terhadap suatu pernyataan dalam angket terbagi menjadi empat kategori yaitu sangat setuju, setuju, tidak setuju, dan sangat tidak setuju. Adapun perhitungan setiap pernyataan adalah sebagai berikut.

$$
\mathrm{P}=\frac{f}{n} x 100
$$

$$
\begin{aligned}
& \text { Keterangan : } \\
& \begin{array}{ll}
\mathrm{P} & =\text { Persentase jawaban } \\
\mathrm{f} & =\text { Frekuensi jawaban } \\
\mathrm{n} & =\text { Jumlah siswa }
\end{array}
\end{aligned}
$$

Tabel 2. Klasisfikasi Perhitungan Tiap Kategori

\begin{tabular}{|c|c|}
\hline Besar Persentase & Interpretasi \\
\hline $0 \%$ & Tidak Ada \\
\hline $01-25 \%$ & Sebagian Kecil \\
\hline $26-49 \%$ & Hampir Setengahnya \\
\hline $50 \%$ & Setengahnya \\
\hline $51-75 \%$ & Sebagian Besar \\
\hline $76-99 \%$ & Pada Umumnya \\
\hline $100 \%$ & Seluruhnya \\
\hline
\end{tabular}


Bentuk angket dibuat menurut skala Likert, yaitu Sangat Setuju (SS), Setuju (S) Tidak Setuju (TS), dan Sangat Tidak Setuju (STS). Setiap kategori jawaban pada pernyataan positif dan negatif memiliki skor yang berbeda seperti yang diuraikan pada tabel berikut ini.

\section{HASIL PENELITIAN}

\section{Hasil Penelitian}

\section{a. Kondisi Awal}

Siswa sekolah dasar pada umumnya merupakan insan yang senang sekali akan aktivitas gerak. Sehingga, mata pelajaran pendidikan jasmani menjadi salah satu mata pelajaran yang selalu di nanti dan sangat disenangi oleh siswa, khususnya oleh siswa kelas III di SD Negeri 05 Karangtengah. Akan tetapi, pada pelaksanaan pembelajarannya kerap kali muncul hambatan yang dapat menurunkan rasa senang siswa tersebut, yaitu pada saat praktek, siswa kurang memahami tentang materi yang diajarkan sehingga berdampak pada kurang optimalnya keterampilan siswa dalam melakukan materi yang diajarkan. Salah satunya adalah pada materi atletik khususnya lari jarak pendek. Permasalahan yang muncul pada siswa dalam teknik melakukan lari jarak pendek kurang serius dan tidak memaksimalkan kecepatan saat melakukan tes hal ini berdampak pada siswa untuk mendapatkan nilai ideal sesuai dengan ketuntasan minimal yang ditetapkan oleh sekolah. Menyikapi permasalahan tersebut, maka peneliti mendiskusikannya bersama kepala sekolah dan wali kelas III di SD Negeri 05 Karangtengah guna diadakannya penelitian sebagai usaha untuk mengatasi permasalahan tersebut.

Berdasarkan hail diskusi peneliti bersama kepala sekolah dan wali kelas III, ditetapkanlah waktu untuk penelitian yaitu selama 1 bulan 3 minggu, dengan siklus sebanyak 3 siklus dan jumlah pertemuan sebanyak 7 kali pertemuan. Terdiri dari 1 kali pertemuan untuk tes prasiklus, dan masing- masing 2 kali pertemuan untuk siklus I, II, dan III. Adapun jadwal pelajaran pendidikan jasmani kelas III dilaksanakan 1 kali dalam seminggu yaitu pada hari kamis mulai dari pukul 07.30 - 09.15 WIB. Berikut adalah jadwal penelitian tindakan kelas yang dilaksanakan di kelas III siswa SD Negeri 05 Karangtengah .

Untuk mengetahui kemampuan awal siswa kelas III di SD Negeri 05 Karangtengah mengenai lari jarak pendek, maka pada hari kamis tanggal 22 Februari 2020 peneliti melaksanakan tes evaluasi prasiklus sebelum memulai tindakan pada siklus I. Tes tersebut diikuti oleh seluruh siswa kelas III di MI Al- Khoeriyyah. Kondisi awal siswa kelas III di SD Negeri 05 Karangtengahdalam melakukan tes lari jarak pendek tersebut yaitu, nilai tertinggi yang diperoleh siswa sebesar 75, terendah 50, dan rata- rata nilai sebesar 62,6, dengan presentase ketuntasan 24\%. Mengacu kepada hasil tersebut maka dapat dikatakan bahwa hasil pembelajaran belum sesuai dengan yang diharapkan. Untuk lebih jelasnya mengenai hasil tes prasiklus, maka data hasil analisis di atas penulis konversikan pada diagram 4.1 di bawah ini :

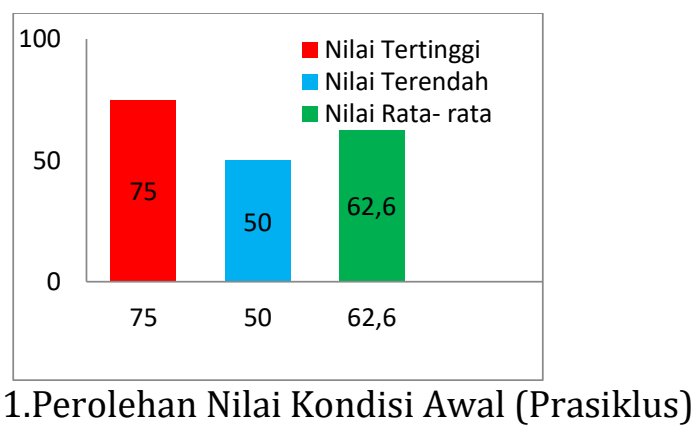

Berdasarkan grafik di atas, diketahui bahwa hasil pembelajaran belum sesuai dengan yang diharapkan. Hal ini dikarenakan proses pembelajaran masih belum maksimal, sehingga siswa 
belum memahami secara jelas tentang teknik lari jarak pendek, tidak adanya pengamatan kinerja guru dan siswa juga mempengaruhi hasil tes tersebut.

Menyikapi permasalahan tersebut, akhirnya pada siklus I peneliti akan menerapkan pembelajaran lari jarak pendek melalui pendekatan bermain lari bola keranjang. Hal tersebut dilakukan dalam upaya meningkatakan lari jarak pendek pada siswa kelas III di SD Negeri 05 Karangtengah.

\section{b. Siklus I}

Berdasarkan analisis hasil evaluasi siklus I diperoleh hasil tertinggi 75 dan terendah 50 dengan nilai rata- rata 67,2 dan persentase ketuntasan 52\%, ini juga berarti hasil pembelajaran belum sesuai dengan yang diharapakan walaupun sudah lebih baik dari hasil pra siklus. Perolehan nilai siklus I pada siswa kelas III di SD Negeri 05 Karangtengah dalam melakukan tes lari jarak pendek. Untuk lebih jelasnya mengenai hasil tes, maka data hasil analisis di atas penulis konversikan pada diagram 4.2 di bawah ini :

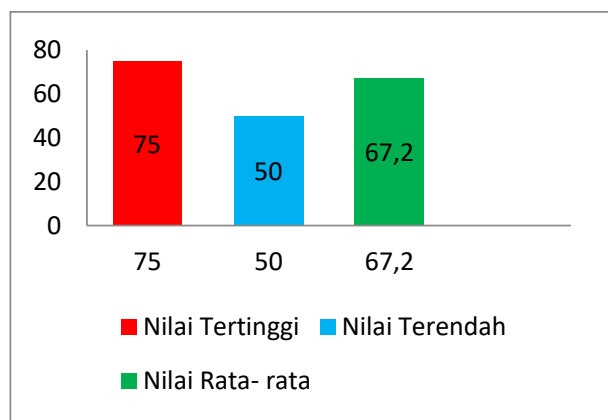

Diagram 2. Perolehan Nilai Siklus I

\section{Siklus II}

Berdasarkan analisis hasil evaluasi pada siklus II diperoleh hasil tertinggi 80 dan terendah 55 dengan nilai rata- rata 71,6 dan persentase ketuntasan $68 \%$, ini juga berarti hasil pembelajaran belum sesuai dengan yang diharapakan walaupun sudah lebih baik dari hasil siklus I. Perolehan nilai siklus II pada siswa kelas III di SD Negeri 05 Karangtengahdalam melakukan tes lari jarak pendek. Untuk lebih jelasnya mengenai hasil tes, maka data hasil analisis di atas penulis konversikan pada diagram 4.3 di bawah ini :

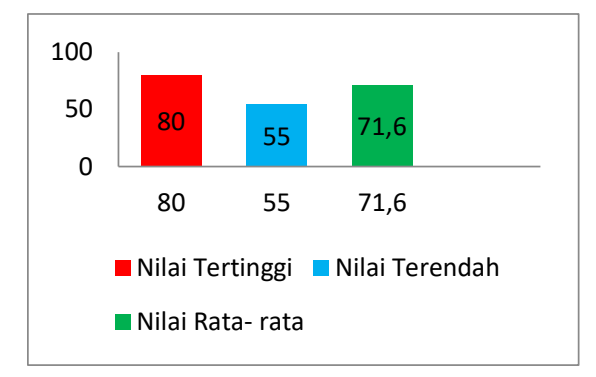

\section{Gambar 3. Perolehan Nilai Siklus II}

\section{Siklus III}

Berdasarkan analisis hasil evaluasi pada siklus III diperoleh hasil tertinggi 90 dan terendah 65 dengan nilai rata- rata 80,2 dan persentase ketuntasan 88\%. Hal ini membuahkan fakta bahwa dalam siklus III menunjukan adanya peningkatan evaluasi dari pembelajaran lari jarak pendek melalui pendekan bermain dibandingkan dengan hasil pembelajaran pada siklus I dan siklus II. Perolehan nilai siklus III pada siswa kelas III di SD Negeri 05 Karangtengah dalam melakukan tes lari jarak pendek. Untuk lebih jelasnya mengenai hasil tes, maka data hasil analisis di atas penulis konversikan pada diagram 4 di bawah ini : 


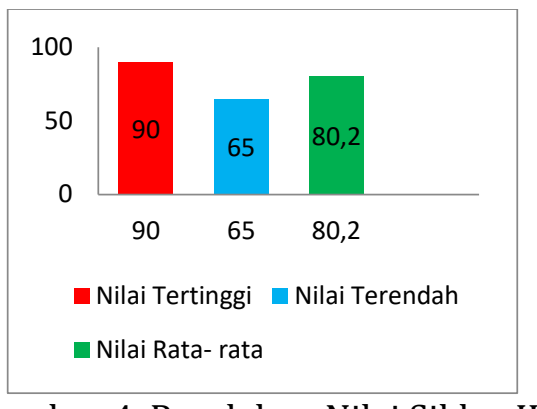

Gambar 4. Perolehan Nilai Siklus III

Berdasarkan hasil kajian di atas pada pelaksanaan siklus III menunjukan adanya peningkatan hasil belajar. Pada siklus I persentase skor observasi guru 72,5\%, observasi siswa $72,5 \%$, nilai rata- rata 67,2 dan ketuntasan belajar 52\%. Sedangkan pada siklus II persentase skor observasi guru $85 \%$, observasi siswa $87,5 \%$, nilai rata- rata 71,6 dan ketuntasan belajar $68 \%$. Sedangkan pada siklus III persentase skor observasi guru 95\%, observasi siswa 95\%, nilai ratarata 80,2 dan ketuntasan belajar $88 \%$.

Peningkatan ini terjadi karena siswa sudah mulai terbiasa dengan pembelajaran lari jarak pendek melalui pendekatan bermain dan murid sudah lebih berani dan percaya diri dalam pembelajaran lari jarak pendek. Selain itu guru sudah dapat mengelola waktu dengan baik, sehingga dalam memberikan bimbingan dan kesimpulan guru tidak terkesan terburu- buru.

Peningkatan ini juga disebabkan karena kepedulian siswa terhadap teman sudah lebih baik. Walaupun masih ada siswa yang masih acuh terhadap temannya dan dalam pengelolaan dalam waktu pembelajaran guru sudah bisa membagi waktu sehingga pada saat memberikan penjelasan dan bimbingan, guru bisa menjalankan semua itu dengan baik. Dari hasil penelitian ini,diperoleh nilai siswa pada kelas III di SD Negeri 05 Karangtengah dapat digambarkan sebagai berikut pada diagram 4.5 kenaikan tiap rata- rata dan diagram 4.6 ketuntasan belajar dari tiap siklus.

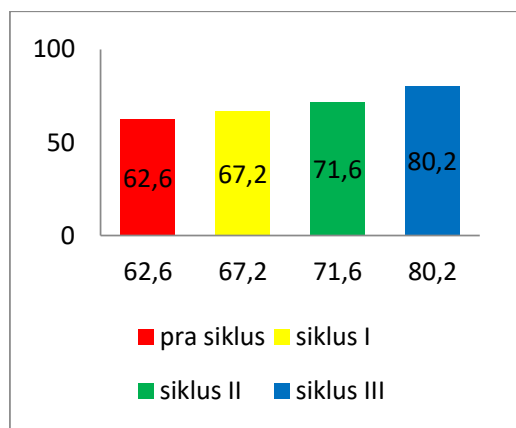

\section{Gambar 5. Kenaikan Rata- rata tiap Siklus}

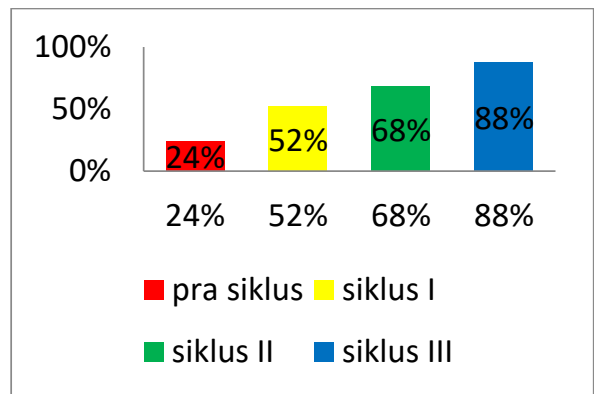

\section{Gambar 6. Persentasi Ketuntasan Belajar Tiap siklus}

Dari gambar di atas menunjukan kenaikan hasil belajar siswa. Data ini diperoleh dari analisa hasil evaluasi dari tiap siklus. Dari hasil analisa tersebut, maka dapat diketahui bahwa hasil 
belajar siswa pada materi lari jarak pendek melalui pendekatan bermain lari bola keranjang ada peningkatan hasil belajar.

\section{Sikap Siswa Terhadap Pembelajaran Lari Jarak Pendek Melalui Pendekatan Bermain Lari Bola Keranjang}

Terjadi perubahan secara signifikan yang terjadi pada siswa setelah melaksanakan pembelajaran lari jarak pendek melalui pendekan bermain lari bola keranjang sesuai dengan diagram 4.5 dan 4.6. Siswa pada umumnya sudah memiliki motivasi yang positif terhadap pembelajaran pendidikan jasmani, terlebih dalam materi lari jarak pendek. Mereka lebih bersunggug- sungguh belajar, lebih percaya diri dan lebih tertarik pada pembelajaran lari jarak pendek melalui pendekatan bermain lari bola kernjang.

Siswa lebih tertarik mengikuti pembelajaran setelah guru memberikat pendekatan bermain lari bola keranjang serta turut membantu siswa dalam memahami dan menguasai materi lari jarak pendek melalui pendekatan bermain, meskipun pada awalnya siswa merasa takut dan kaku dalam melakukan lari jarak pendek tetapi setelah dibimbing secara terus menerus oleh guru pada akhirnya siswa mampu melakukan lari jarak pendek melalui pendekatan bermain lari bola keranjang dengan mengalami peningkatan.

Setelah pembelajaran pada siklus III berakhir, peneliti memberikan angket kepada siswa yang bertujuan untuk mengetahui tanggapan dan respon siswa mengenai pembelajaran yang telah dilaksanakan selama siklus I dan siklus III.

Angket terdiri atas 13 item pernyataan yang bersifat positif dan 7 item pernyataan negatif. Dalam pengerjaannya, seluruh siswa mengenai kolom jawaban yang diberikan atas salah satu pernyataan sesuai pendapat mereka masing- masing. Hasil jawaban siswa tersebut disajikan kedalam tabel berikut:

Dari perhitungan angket dapat dijelaskan hasil analisis angket sebagai berikut :

1. "Pembelajaran lari jarak pendek melalui pendekatan bermain menggairahkan belajar saya" sebagian besar siswa menjawab sangat setuju (52\%), hampir setengahnya menjawab setuju (36\%), sebagian kecil menjawab tidak setuju (8\%) dan sebagian kecil menjawab sangat tidak setuju $(4 \%)$

2. "Dengan pendekatan bermain saya menjadi lebih semangat dalam pembelajaran lari jarak pendek" dalam sebagian besar siswa menjawab sangat setuju (52\%), hampir setengahnya menjawab setuju (40\%), sebagian kecil siswa menjawab tidak setuju (8\%), dan tidak ada siswa menjawab sangat tidak setuju(0\%).

3. "Pendekatan bermain membuat saya lebih mudah melakukan pembelajaran lari jarak pendek" dalam sebagian besar siswa menjawab sangat setuju (52\%), hampir setengahnya menjawab setuju (40\%), sebagian kecil siswa menjawab tidak setuju (8\%), dan tidak ada siswa menjawab sangat tidak setuju $(0 \%)$.

4. "Saya senang pembelajaran lari jarak pendek melalui pendekatan bermain" dalam pertanyaan ini hampir setengahnya menjawab sangat setuju (48\%), hampir setengahnya juga menjawab setuju (36\%), sebagian kecil siswa menjawab tidak setuju (12\%), dan sebagian kecil lagi siswa menjawab sangat tidak setuju (4\%).

5. "Saya sering melakukan teknik dengan benar akibat adanya belajar melalui pendekatan bermain" sebagian besar siswa menjawab sangat setuju (64\%), sebagian kecil siswa menjawab setuju (24\%), sebagian kecil juga siswa menjawab tidak setuju (12\%) dan tidak ada siswa menjawab sangat tidak setuju (0\%).

6. "Saya menjadi lebih semangat belajar dengan adanya pembelajaran melalui pendekatan bermain" sebagian besar siswa menjawab sangat setuju (52\%), hampir setengahnya siswa setuju (36\%), sebagian kecil siswa menjawab tidak setuju (8\%) dan sebagian kecil juga siswa menjawab sangat tidak setuju (4\%).

7. "Pendekatan bermain membuat pembelajaran saya kurang maksimal" hampir setengahnya siswa menjawab sangat setuju (44\%), hampir setengahnya juga siswa setuju (36\%), sebagian kecil siswa tidak setuju (12\%) dan sebagian kecil juga siswa sangat tidak setuju (8\%). 
8. "Saya kurang bersemangat dengan adanya pembelajaran melalui pendekatan bermain" hampir setengahnya siswa menjawab sangat setuju (40\%), hampir setengahnya menjawab setuju (40\%), sebagian kecil menjawab tidak setuju (4\%) dan sebagian kecil menjawab sangat tidak setuju(16\%).

9. "Pendekatan bermain dapat mengembangkan kemampuan saya dalam melakukan lari jarak pendek" sebagian besar siswa menjawab sangat setuju (60\%), hampir setengahnya (32\%), sebagian kecil tidak setuju (8\%), dan tidak ada yang menjawab sangat tidak setuju (0\%).

10. "Saya dapat lebih mengerti dengan gerakan-gerakan yang harus dilakukan dalam belajar lari jarak pendek" sebagian besarsiswa menjawab sangat setuju (56\%), hampir setengahnya menjawab setuju (36\%), sebagian kecil tidak setuju (8\%), dan tidak ada yang menjawab sangat tidak setuju (0\%).

11. "Saya jenuh dan bosan dengan pembelajaran yang menggunakan pendekatan bermain" hampir setengahnya siswa menjawab sangat setuju (44\%), hampir setengahnya setuju (32\%), sebagian kecil tidak setuju (8\%), dan sebagian kecil sangat tidak setuju (16\%).

12. "Dengan pembelajaran menggunakan pendekatan bermain pembelajaran menjadi riang dan menyenangkan" sebagian besar sangat setuju (52\%), hampir setengahny setuju (32\%), sebagian kecil tidak setuju (12\%), dan sebagian kecil sangat setuju (4\%).

13. "Belajar menggunakan pendekatan bermain menjadikan saya lebih mengerti pentingnya teknik dalam lari jarak pendek" hampir setengahnya sangat setuju (48\%), hampir setengahnya setuju (40\%), sebagian kecil tidak setuju (4\%), dan sebagian kecil sangat tidak setuju (8\%).

14. "Pembelajaran menggunakan pendekatan bermain membuat semangat saya menurun" hampir setengahnya siswa menjawab sangat setuju (36\%), hampir setengahnya setuju (44\%), sebagian kecil tidak setuju (4\%), dan sebagian kecil sangat tidak setuju (16\%).

15. "Dengan menggunakan pendekatan bermain membuat saya tidak kesulitan untuk belajar lari jarak pendek" sebagian besar sangat setuju (64\%), hampir setengahnya setuju (36\%), tidak aada yang menjawab tidak setuju dan sangat tidak setuju $(0 \%)$.

16. "Saya merasa terbebani dengan model belajar yang diberikan setiap pertemuan" hampir setengah sangat setuju (32\%), hampir setengah setuju (28\%), sebagian kecil tidak setuju (28\%), dan hampir setengahnya sangat tidak (32\%).

17. "Saya takut salah melakukan teknik lari jarak pendek" hampir setengah sangat setuju (36\%), sebagian kecil setuju (28\%), sebagian kecil tidak setuju (8\%) dandan hampir setengahnya sangat tidak (32\%).

18. "Pendekatan bermain kurang bermanfaat untuk peningkatan lari jarak pendek" hampir setengahnya sangat setuju(32\%), hampir setengahnya menjawab sangat setuju (28\%), sebagian kecil tidak setuju (8\%), hampir setengahnya sangat tidak setuju (32\%).

19. "Saya merasa semangat dalam proses pembelajaran yang saya ikuti" hampir setengahnya siswa menjawab sangat setuju (48\%), hampir setengahnya setuju (32\%), sebagian kecil tidak setuju (12\%) dan sebagian kecil sangat tidak setuju (4\%).

20. "Setelah pembelajaran melalui pendekatan bermain saya menjadi menyukai pembelajaran lari jarakpendek" sebagian besar siswa menjawab sangat setuju (60\%), hampir setengahnya menjawab (32\%),dan sebagian kecil tida setuju (8\%) dan tidak ada yang menjawab sangat tidak setuju.

\section{PEMBAHASAN}

Setelah dilakukan pengolahan dan analisis terhadap data hasil penelitian, maka pada bagian ini akan dibahas mengenai hasil dan temuan penelitian. Pembahasan tersbut akan difokuskan pada permasalahan yang telah dikemukakan pada Bab I.

Hasil pembelajaran siswa selama peroses pembelajaran lari jarak pendek melalui pendekatan bermain lari bola keranjang mengalami peningkatan tiap siklusnya. Untuk hasil belajar pra siklus (kondisi awal) rata-rata nilai tes adalah 62,6, tentu saja pencapaian ini masih 
jauh dari harapan. Hal ini disebabkan karena siswa kurang serius dalam pembelajaraan sehingga terkesan acuh terhadap apa yang telah diberikan oleh guru atau dalam hal ini peneliti. Guru dalam memberikan penjelasan dan bimbingan materi juga kurang begitu menarik, mengakibatkan siswa tidak memperhatikan dengan baik. Sehingga pengkondisian guru terhadap siswa rendah dan membuat kondisi pembelajaran kurang efektif.

Pada siklus I rata- rata nilai mencapai 67,2. Hal ini terjadi karena siswa pada saat pembelajaran kelompok belum sepenuhnya berjalan dengan baik, sehingga penguasaan materi masih kurang. Akibatnya, pada saat evaluasi mereka tidak dapat melakukan teknik lari jarak pendek dengan baik, namun adaptasi siswa terhadap media pembelajaran sudah mulai mengalami ada peningkatan dengan adanya tindakan ingin terus mengulangi latihan teknik lari jarak pendek.

Pada siklus II nilai rata-rata siswa meningkat menjadi 71,6. Hal ini menunjukan bahwa siswa sudah mulai terbiasa dengan pembelajaran lari jarak pendek melalui pendekatan bermain lari bola keranjang. Kemudian mereka melakukan latihan secara berkelompok dan kegiatan pembelajaran mulai berjalan dengan lebih baik dengan banyaknya minat siswa untuk terus mencoba melakukan teknik lari jarak pendek melalui pendekatan bermain lari bola keranjang dan pengetahuan diperoleh siswa lebih meningkat, karena pengetahuan tidak hanya bersumber dari guru saja tetapi juga bertambah dari hasil diskusi atau bertanya kepada teman dalam kelompoknya, dan pada saat evaluasi sebagian besar siswa dapat melakukan lari jarak pendek dengan baik.

Pada siklus III nilai rata- rata siswa meningkat menjadi 80,2, hal ini menunjukan bahwa siswa sudah mulai terbiasa dan mulai serius dalam pembelajaran lari jarak pendek melalui pendekatan bermain lari bola keranjang. Siswa melakukan lari jarak pendek dengan tidak canggung dan malumalu selain itu adanya sifat saling membantu kepada teman yang masih belum bisa melakukan pembelajaran lari jarak pendek.

Penilaian ini dilakukan pada saat siswa melakukan pembelajaran. Dengan media pembelajaran yang mudah untuk dimainkan oleh semua siswa serta pembelajaran kelompok juga mendukung peningkatan aktivitas komunikasi siswa. Dengan adanya pembelajaran melalui pendekan bermain, siswa menjadi lebih aktif dan tidak merasa jenuh saat melakukan pembelajaran.

Keaktifan siswa senantiasa mendorong tingkat keberhasilan dalam pembelajaran, dan yang lebih penting adaptasi siswa terhadap media pembelajaran semakin meningkat, siswa sudah mulai nyaman dan dengan senang melakukan lari jarak pendek karena adanya pendekatan bermain.

Dari hasil jawaban angket, siswa merasa bahwa pembelajaran melalui pendekatan bermain lebih memberikan kemudahan mereka dalam pembelajaran serta dengan kerjasama kelompok mereka lebih berinteraksi dengan teman lebih cepat dalam memahami setiap materi yang diberikan dibandingkan dengan pembelajaran sebelumnya. Walaupun pembelajaran berpusat pada siswa, akan tetapi guru tetap mempunyai arti penting sebagai fasilitator yang mengarahkan siswa untuk berpartisifasi aktif selama proses pembelajaran dan untuk mengeluarkan semua kemampuan dan potensi yang dimiliki oleh setiap siswa untuk lebih berani dan tampil dengan percaya diri.

Pembelajaran lari jarak pendek melalui pendekatan bermain lari bola kernjang pada penelitian ini umumnya sesuai dengan rencana dan tujuan akhir yang diinginkan, walaupun perlu usaha yang cukup berat dalam pencapaiannya. Secara umum pembelajaran ini berjalan dengan efektif, kreatif, efisien, dan memberikan kontribusi yang cukup berarti dalam meningkatkan hasil belajar siswa pada pokok bahasan lari jarak pendek.

\section{KESIMPULAN}

Berdasarkan hasil analisis data yang telah dilakukan, penerapan pembelajaran lari jarak pendek melalui pendekatan bermain lari bola keranjang terjadi perubahan aktivitas siswa dalam lari jarak pendek. Ini terlihat dari persentase yang terus meningkat dari siklus I sampai siklus III. Secara signifikan terjadi peningkatan aktivitas siswa menjadi lebih baik. 
Penerapan pembelajaran lari jarak pendek melalui pendekatan bermain lari bola keranjang dapat meningkatkan kemampuan siswa dalam melakukan lari jarak pendek.hal ini terbukti dari hasil tes/ evaluasi yang dilaksanakan dari tiap siklus terdapat peningkatan dari siklus I, siklus II sampai siklus III. Berdasarkan data tersebut dapat disimpulkan bahwa pembelajaran lari jarak pendek melalui pendekatan bermain lari bola keranjang dapat meningkatkan hasil belajar pendidikan jasmani siswa.

Hasil analisis angket dapat disimpulkan bahwa dengan pendekatan bermain lari bola keranjang siswa menjadi lebih semangat dan aktif dalam proses pembelajaran, merasa lebih termotivasi untuk memahami materi pelajaran pendidikan jasmani, siswa juga mersa terbantu dalam mengatasi masalah dan menyelesaikan tes/ evaluasi dengan adanya pembelajaran lari jarak pendek melalui pendekatan bermain lari bola keranjang siswa menyatakan sangat setuju jika pendekatan bermain membuat senang dan bersemangat dalam belajar. Hal tersebut menunjukan bahwa pembelajaran melalui pendekatan bermain lebih berhasil meningkatkan pembelajaran atletik khusunya lari jarak pendek.

\section{DAFTAR PUSTAKA}

1. Tedi, Muhammad. (2017). Peningkatan Pembelajaran Lari Jarak Pendek melalui Pendekatan Bermain Bola Keranjang Pada Siswa Kelas III Melalui Pendekatan Bermain Lari Bola Keranjang Pada Siswa Kelas III di MI Al-Khoeriyyah Kecamatan Pacet Kabupaten Cianjur. Skripsi Pada Program PJKR Universitas Surya Kencana: tidak diterbitkan

2. Yaya Suryana, Tedi Priatna, (2007). Metode Penelitian Pendidikan. Bandung: Azkia Pustaka Utama.

3. Rosdiani Dini. (2012). Model pembelajaran langsung dalam Pendidikan Jasmani dan Kesehatan. Bandung. Alfabeta.

4. Rosdiani Dini. (2013). Perencanaan Pembelajaran dalam Pendidikan Jasmani Kesehatan dan Rekreasi. Bandung. Alfabeta.

5. Zafar Sidiq, Dikdik (2011). Mengajar dan Melatih Atletik. Bandung: PT Remaja Rosdakarya.

6. Husdarta, H.J.S., Yudha M. Saputra. (2010). Belajar dan Pembelajaran Pendidikan Jasmanikes. Bandung: Dewa ruchi.

7. Hartono, Budi. Skripsi ( Pembelajaran Lari Jarak Pendek Menggunakan Pendekatan Permainan Pada Siswa Kelas III SD Negeri Muncang Larang 03 Kecamatan Bumijawa Kabupaten Tegal Tahun Pelajaran 2012/ 2013. Semarang: Universitas Negeri Semarang.

8. Rizmansyah, R. Windar. Skripsi (Peningkatan keterampilan smash dalam permainan bulutangkis melalui modifikasi raket di kelas x SMK Kujang Pilawa Cianjur. Cianjur: Universitas Suryakancana Cianjur. 